\title{
Farklı dozlarda tuz ve mikoriza uygulamalarının biberde hormon, antioksidan, fenolik ve organik asit içeriklerine etkisi
}

The effect of different doses of salt and mycorrhiza applications on hormone, antioxidant, phenolic and organic acid contents in peppers

\section{K. Mesut ÇiMRiN ${ }^{1 \mathcal{O}}(\mathbb{D})$, Hakan BAŞAK ${ }^{2}$ (D) Metin TURAN ${ }^{3}$}

${ }^{1}$ Hatay Mustafa Kemal University, Faculty of Agriculture, Department of Plant Protection, Antakya-Hatay, Turkey.

${ }^{2}$ Ahi Evran University, Faculty of Agriculture, Department of Horticulturae, Kırşehir, Turkey.

${ }^{3}$ Yeditepe University, Faculty of Engineering and Architecture, Department of Genetics and Bioengineering, Istanbul, Turkey.

MAKALE BILGISI / ARTICLE INFO

Makale tarihçesi / Article history:

DOI: $10.37908 /$ mkutbd.793222

Geliş tarihi /Received:10.09.2020

Kabul tarihi/Accepted:29.09.2020

\section{Keywords:}

Mycorrhiza, salt stress, hormone, phenolic, antioxidant, organic acid.

\footnotetext{
Corresponding author: K. Mesut ÇiMRiN

$\triangle$ : mcimrin@hotmail.com
}

\section{Ö ZET / A B STR A C T}

\begin{abstract}
Aims: In the study, mycorrhiza (ROOTS-novozymes endo-mycorrhiza (VAM) fungus (Glomus spp.)) and increasing salt doses of the root and stem tissues of pepper plant (Capsicum annuum L.); It was aimed to determine the effects on hormone, total phenolic and organic acid contents and total antioxidant capacity.

Methods and Results: In the study conducted in the greenhouse according to the random block design, pepper plants were applied to the soil in four different doses of salt (To: $0, T_{50}: 50, T_{100}: 100$ and $T_{150}: 150 \mathrm{mM} \mathrm{NaCl}$ ) and two doses of mycorrhizal (Mo: 0, M100: 100 spores / plant) were applied, with and without mycorrhiza. In the study, the levels of GA, SA and IAA in the root and stem tissues decreased statistically significantly with the effect of increasing salt doses. ABA content of pepper plant increased significantly with the increase in salt doses in root and stem tissues of plants not applied mycorrhiza, while the increase in salt doses in plants treated with mycorrhiza did not affect the content of ABA. ABA content, which was determined at only $50 \mathrm{mM}$ salt dose, was found to be significantly higher in those applied to mycorrhiza than those without mycorrhiza. While the total phenolic content and antioxidant capacity decreased significantly in root and stem tissues due to the salt stress, it was found to be the highest in 50 $\mathrm{mM} \mathrm{NaCl}$ applied mycorrhizal plants. Organic acid contents increased in root and stem tissues compared to control plants with the increase in the applied salt doses, except stem tartaric and maleic acid and root maleic acid. Stem butyric, malonic and malic acid contents of plants treated with mycorrhiza were determined higher than those without mycorrhiza, while malonic and malic acid contents of root tissues were higher in those with mycorrhiza.

Conclusions: It has been determined that mycorrhiza is effective in showing stress tolerance due to the increase in total phenolic and antioxidant content as well as ABA level in the stem and root tissues at $50 \mathrm{mM}$ salt dose, but this positive effect is impaired at higher salt concentrations.

Significance and Impact of the Study: As a result, it can be said that the mycorrhiza improves plant tolerance at moderate salt stress, but is ineffective at high and very high salt stress.
\end{abstract}

Atıf / Citation: Çimrin KM, Başak H, Turan M (2020) Farklı dozlarda tuz ve mikoriza uygulamalarının biberde hormon, antioksidan, fenolik ve organik asit içeriklerine etkisi. MKU. Tar. Bil. Derg. 25(3) : 488-498. DOI: 10.37908/mkutbd.793222 


\section{GíRiş}

Bitkilerde büyüme ve gelişmeyi olumsuz etkileyen tuzluluk, verim ve kaliteyi sınırlandıran en önemli abiyotik stres faktörlerinden birisidir. Dünya üzerinde özellikle kurak ve yarı kurak bölgelerde global bir sorun haline gelen tuzluluk problemi tarım arazilerinin \%20'sini tehdit etmekte olup, önlem alınmaz ise bu oranın önümüzdeki 20 yıl içerisinde $\% 50$ 'lere ulaşabileceği öngörülmektedir (Hasanuzzaman ve ark., 2013). Ülkemizde de tuz etki etmiş alanların yaklaşık 2 milyon ha olduğu bildirilmektedir (Anonim, 2018). Tuz stresi bitkilerde besin elementlerinin alınımını azaltarak ve iyon dengesini bozarak (Ashraf ve Bhatti, 2000), toprağın osmotik basıncını artırıp fizyolojik kuraklığa neden olarak (Parida ve Das, 2005), daralan stomaların $\mathrm{CO}_{2}$ alımını düşürmesi sonucu fotosentezi azaltarak, oluşturduğu stres sonucu serbest oksijen radikallerinin oluşumunu artırarak (Tambussi ve ark., 2000), membran zararlanması ve lipid peroksidasyonuna sebep olarak (Kalefetoğlu ve Ekmekçi, 2005) bitkilerde büyüme ve gelişmeyi olumsuz etkilemektedir.

Tuzluluk ile mücadelede mikrobiyal uygulamalar gerek uygulama pratikliği ve etkinliklerinin uzun süreli olması, gerekse de tuza toleransı önemli düzeyde artırmaları nedeniyle tüm dünyada yaygın olarak tercih edilmektedir. Mikrobiyal uygulamalar içerisinde en etkili alternatiflerden birisi de mikorizadır. Bitki kökleri ile simbiyotik ilişki kurabilme yeteneğine sahip olan mikoriza mantarları, bitkiden kendisinin sentezleyemediği karbonhidratları hazır alırken, hifleri sayesinde bitkilerin kök etki alanını genişleterek daha fazla su ve besin elementi alabilmelerine katkı sağlamaktadır (Smith ve Read, 1997). Mikorizanın olumlu etkisi sadece su ve besin elementlerinin alınımını artırması olmayıp, bitkilerin abiyotik ve biyotik stres koşullarına toleransını da yükseltmektedir (Ruiz-Lozano, 2003; Carvalho ve ark., 2004).

Bitkiler tuz stresinin üstesinden gelebilmek için bazı biyokimyasal mekanizmalar geliştirmiştir. Başka bir değişle, bitkilerde tuz toleransı ile ilgili olarak çeşitli inorganik ve organik bileşenlerin birikimi söz konusudur. Tuz stresi sırasında biriken amino asitler, amidler, imino asitler gibi bileşiklerin bu koşullarda büyüyen bitkilerde önemli rol oynadıkları, bu maddelerin ozmotik düzenlemeye olan katkıları türler, çeşitler ve dahası bitkinin farklı organları arasında ayrıcalık göstermektedir (Ashraf, 1994). Stres koşulları altında biriken bu bileşiklerin ozmotik düzenleme, hücresel makro moleküllerin korunması, azotun depolanması, hücresel $\mathrm{pH}^{\prime} ı$ n sürdürülmesi, hücrelerin detoksifikasyonu ve serbest radikallerin temizlenmesi gibi olaylarda fonksiyon gördüğü ileri sürülmektedir (Guo ve ark., 2010; Yang ve ark., 2007; Hatzig ve ark., 2010). Benzer olarak, azot içeren bileşiklerin birikimi genellikle bitki tuz toleransı ile ilişkilendirilmiştir (Mansour, 2000). Bitki hormonları (Oksin, gibberellin, sitokinin ve absisik asit) mikorizal simbiyoz süreci sırasında sinyal molekülleri olarak işlev görmektedirler (Guo ve ark., 2010; Miransari, 2012). Mikoriza ile kurulan simbiyotik ilişkinin bir sonucu olarak, bitki hormonlarının seviyesi ve sentezlenen enzimlerin üretimi değişim göstermektedir (López-Ráez ve ark., 2010). Bitkilerin tuz stresine karşı tolerans artırmasında antioksidan sistemlerin aktif hale getirilmesi önemli rol oynar. Antioksidan aktivite özelliğine sahip fenolik bileşikler, yörüngelerinde eşleşmemiş elektron bulunduran serbest radikallere hidrojen vererek onları etkisiz hale getirmektedir (Ruiz ve ark., 2003; Es-Safi ve ark., 2007). Bitkiler organik asit metabolizmalarında yaptıkları düzenlemelerle tuz stresine karşı tolerans gösterebilirler (Guo ve ark., 2010). Organik asit seviyesindeki artış, katyonlara karşı iyon görevi görerek strese karşı toleransı artırabilir, bitki hücrelerinde klor birikimini önler, pH'nın düzenlenmesine ve osmotik dengenin korunmasına katkı sağlar (Yang ve ark., 2007; Guo ve ark., 2010; Hatzig ve ark., 2010). Mikorizal simbiyosisin bitkilerin tuz stresine karşı toleransını arttırdığı; çilek (Sharma ve Adholeya, 2004), domates (Şensoy, 2007; Başak ve ark., 2011), biber (Altunlu, 2019), patlıcan (Mohammad and Mittra, 2013), kabak (Colla ve ark., 2008) ve fasulye (Sharma ve ark., 2017) gibi birçok bitkide belirlenmiştir. Ancak mikoriza uygulamasının tuz stresi altındaki bitkilerin toplam fenolik ve organik asit içerikleri ile toplam antioksidan kapasitesi üzerine etkisi yeterince araştırılmamıştır.

Çalışma ile bitkilerin tuz stresine karşı tolerans gösterebilmesinde mikoriza simbiyozunun bitkilerdeki temel fizyolojik ve biyokimyasal olaylara etki mekanizmasının daha iyi anlaşılmasına katkı sağlayacağı öngörülmektedir.

\section{MATERYAL ve YÖNTEM}

Araştırma Kırşehir Ahi Evran Üniversitesi Ziraat Fakültesine ait iklim kontrollü serada toprak doldurulmuş saksılarda tesadüf blokları deneme desenine göre dört tekrarlamalı olarak yürütülmüştür. Çalışmada Kırşehir ilinde sebze tarımı yapılan Ökse bölgesinden alınan toprak kullanılmıştır. Denemenin yürütüldüğü toprak $2 \mathrm{~mm}$ ' lik elekten geçirilmiş ve bünye Bouyoucos hidrometre (Bouyoucos, 1951), toprak reaksiyonu $(\mathrm{pH})$ 1:2.5 toprak: su karışımında cam elektrotlu $\mathrm{pH}$ metre ve toplam tuz (Jackson, 1958)'a 
göre, kireç Scheibler kalsimetresi ile (Allison ve Moodie, 1965), toplam azot Kjeldahl yöntemine (Bremner, 1996), alınabilir potasyum (Knudsen ve ark., 1982), yarayışlı fosfor Olsen ve ark. (1954) tarafından bildirildiği şekilde belirlenmiştir. Topraktaki yarayışlı demir (Fe), çinko (Zn), mangan $(\mathrm{Mn}$ ) ve bakır ( $\mathrm{Cu}$ ) DTPA ile ekstrakte edilerek atomik absorpsiyon aletinde belirlenmiştir (Lindsay ve Norvell, 1978; Çizelge 1). Elde edilen bulgulara göre, tınlı bünyeli deneme toprağı; azotça fakir, fazla kireçli, tuzluluk sorunu olmayan, yarayışlı fosforca fazla, değişebilir potasyum miktarı açısından zengindir. Deneme toprağının yarayışlı demir, çinko, mangan ve bakır miktarı yeterli düzeyin üstündedir (Lindsay ve Norvell, 1978).

Bitkisel materyal olarak kendine has hafif acımsı tadı ve ince meyve eti kalınlığı ile tüketici tarafından yoğun şekilde tercih edilen, Kırşehir ilinde biber üreticileri tarafından yetiştiriciliği en fazla yapılan ve tuzluluğa orta derecede toleranslı (Emirzeoğlu ve Başak, 2020) yerel dolmalık biber genotipi (Capsicum annuum L. cv. Cemele) kullanılmıştır. Biber tohumları torf-perlit (2:1) karışımı doldurulmuş viyollere ekilmiş ve dikime hazır hale gelinceye kadar rutin bakım işlemleri Vural ve ark. (2000)'nın önerdiği şekilde yapılmıştır. Biber fidelerine saksılara şaşırtma öncesinde bitki başına 0 ve 100 adet mikoriza sporu aşılanacak şekilde $\left(\mathrm{M}_{0}, \mathrm{M}_{100}\right)$ mikorizanın (ROOTS-novozymes, endo-mycorrhiza fungus (VAM)) iki dozu uygulanmıştır. Biber fideleri, içerisine drenajı engellemek amacı ile plastik torba yerleştirilmiş ve $1.5 \mathrm{~kg}$ hava kuru toprak konulmuş saksılara her saksıda bir bitki olacak şekilde şaşırtılmıştır. Bitkilere mikoriza inokulasyonun tam sağlanabilmesi için şaşırtma tarihinden itibaren 7 gün beklendikten sonra $0 \mathrm{mM}, 50$ $\mathrm{mM}, 100 \mathrm{mM}$ ve $150 \mathrm{mM} \mathrm{NaCl}$ olmak üzere dört tuz dozu ( $T_{0}: T_{50}, T_{100}$ ve $T_{150} \mathrm{mM} \mathrm{NaCl}$ ) uygulanmıştır. Yüksek tuz dozlarının bitkilerde şok etkisi oluşturmaması için tuz uygulamasına $50 \mathrm{mM}$ dan başlanarak, kademeli olarak 150 mM'a kadar artırılmıştır. Deneme süresince bitkiler saf su ile sulanmış ve dikimden sonraki 44. günde deneme sonlandırılarak bitkiler kök boğazından kesilmiş, gövde ve kök örnekleri ayrılmıştır.

Hormon analizi için ekstraksiyon ve saflaştırma işlemleri Davies (1995)'e göre yapılmıştır. İndol asetik asit (IAA), giberellik asit (GA), salisilik (SA) ve absisik asit (ABA) analizlerinde yüksek performanslı sIVı kromatografisi (HPLC) kullanılmıştır (Horgan ve Kramers, 1979, Koshimizo ve Iwamura, 1986; Morris ve ark., 1990). Organik asitler, Zorbax Eclipse-AAA $4.6 \times 250 \mathrm{~mm}, 5 \mathrm{um}$ kolon (Agilent $1200 \mathrm{HPLC}$ ) ve UV detektöründe $220 \mathrm{~nm}$ absorbans kullanılarak HPLC ile belirlenmiştir.

Çizelge 1. Deneme toprağının bazı fiziksel ve kimyasal özellikleri

Table 1. Some physical and chemical properties of the experiment soil

\begin{tabular}{llll}
\hline Kil (\%) & 22.2 & $\mathrm{~N}(\%)$ & 0.071 \\
Kum (\%) & 35.8 & Yarayışlı P $\left(\mathrm{mg} \mathrm{kg}^{-1}\right)$ & 55.0 \\
Silt (\%) & 42.0 & Değişebilir K $\left(\mathrm{mg} \mathrm{kg}^{-1}\right)$ & 600.0 \\
Tekstür sınıfı & Tın & Yarayışlı Fe $\left(\mathrm{mg} \mathrm{kg}^{-1}\right)$ & 6.46 \\
pH $(1: 2.5 \mathrm{su})$ & 7.72 & Yarayışlı Zn $\left(\mathrm{mg} \mathrm{kg}^{-1}\right)$ & 4.05 \\
Tuz $\left.(\mu \mathrm{s} \mathrm{cm})^{-1}\right)$ & 0.209 & Yarayışlı Cu $\left(\mathrm{mg} \mathrm{kg}^{-1}\right)$ & 1.71 \\
Kireç $(\%)$ & 14.6 & Yarayışı Mn $\left(\mathrm{mg} \mathrm{kg}^{-1}\right)$ & 29.08 \\
\hline
\end{tabular}

Organik asitler, mobil faz olarak $25 \mathrm{mM} \mathrm{KH}_{2} \mathrm{PO}_{4}(\mathrm{pH} 2.5)$ kullanılarak analiz edilmiştir (Siddiqui ve ark., 2015). Toplam fenolik içerik miktarı spektrofotometrik (Karanlıkta $23^{\circ} \mathrm{C}^{\prime}$ de 90 dakika inkübasyon sonrası $760 \mathrm{~nm}$ absorbans ölçülerek) yöntemle Siddiqui ve ark. (2015)'na göre $g$ taze ağırlık başına mg gallik asit eşdeğeri (mg GAE $\mathrm{g}^{-1}$ ) olarak belirlenmiştir. Toplam antioksidan kapasitesi tayini ise; DPPH (2,2-diphenyl-1-picryl-hydrazylhydrate), ABTS (2,2-Azino-bis-3-ethylbenzothiazoline6sulfonic Acid) $\beta$-karoten-linoleik asit metodu kullanılarak $\mathrm{g}$ taze ağırlık başına $\mu \mathrm{mol}$ Trolox eşdeğeri ( $\left.\mu \mathrm{mol} \mathrm{TE} \mathrm{g}^{-1} \mathrm{TA}\right)$ olarak belirlenmiştir (Surender Reddy ve ark., 2015). Artan dozlarda tuz stresi uygulanmıs biber bitkilerine mikoriza aşılamasının incelenen parametreler üzerine etkilerini belirlemek için yapılan varyans analizi sonucunda istatistiksel açıdan önemli bulunan ortalamalar arasındaki farklar Duncan testi ile belirlenmiştir (Düzgüneş ve ark., 1987).

\section{BULGULAR ve TARTIŞMA}

\section{Kök ve gövde dokularının GA, SA, IAA ve ABA düzeyleri}

Tuz stresi ve mikoriza uygulamasının biber bitkilerinde kök ve gövde dokularının gibberellik asit (GA), salisilik asit (SA), indol asetik asit (IAA) ve absisik asit (ABA) düzeyleri üzerine etkisi Çizelge 2 ve 3 'te verilmiştir. Artan tuz dozlarının etkisiyle kök ve gövde GA, SA ve IAA içerikleri önemli düzeyde azalmıştır. Mikoriza uygulanmamış bitkilerin gövde ve kök dokularının ABA düzeyi ise tuz dozlarındaki artışla beraber istatistiksel olarak önemli düzeyde artmıştır $(P<0.001)$. Ancak, mikoriza uygulanmış bitkilerde tuz dozlarındaki artışa 
rağmen kök ve gövde $A B A$ düzeylerinde kendi aralarında önemli bir değişiklik belirlenmemiştir. Stres koşullarında artmasından dolayı stres hormonu olarak kabul edilen ABA'nın artan tuz dozlarına rağmen sentezinde artış tespit edilmemesi, mikorizanın bitkileri tuz stresinin olumsuz etkisinden tam olmasa da bir nebze koruduğunun bir kanıtı olarak yorumlanabilir. Tuz stresi uygulanmamış mikorizası $\left(\mathrm{M}_{0} \mathrm{~T}_{0}\right)$ bitkilere kıyasla mikorizalı ( $\mathrm{M}_{100} \mathrm{~T}_{0}$ ) bitkilerin, kök ve gövde $\mathrm{GA}$, SA ve IAA düzeylerinde (gövde GA düzeyi hariç) istatistiksel olarak önemli bir değişiklik belirlenmemiştir. Ancak kök ve gövde dokularının ABA içerikleri, tuz stresi uygulanmamış mikorizalı $\left(\mathrm{M}_{100} \mathrm{~T}_{0}\right)$ ve mikorizasız $\left(\mathrm{M}_{0} \mathrm{~T}_{0}\right)$ bitkilerde kontrol bitkilerine kıyasla daha yüksek tespit edilmiştir (Çizelge 2 ve 3 ).

Çizelge 2. Mikoriza ve tuz uygulamalarının kök hormon içerikleri üzerine etkisi (ng $\mu \mathrm{L}^{-1}$ )

Table 2. Effect of mycorrhiza and salt applications on root hormone contents ( $n g \mu L^{-1}$ )

\begin{tabular}{cllllll}
\hline \multicolumn{2}{c}{ Uygulamalar } & $\mathbf{N}$ & $\mathbf{G A}$ & $\mathbf{S A}$ & IAA & ABA \\
\hline & $\mathbf{T}_{\mathbf{0}}$ & $\mathbf{4}$ & $40.85 \pm 3.61 \mathrm{a}$ & $8.20 \pm 0.54 \mathrm{a}$ & $0.53 \pm 0.02 \mathrm{a}$ & $0.13 \pm 0.03 \mathrm{c}$ \\
& $\mathbf{T}_{\mathbf{5 0}}$ & $\mathbf{4}$ & $31.70 \pm 2.33 \mathrm{~b}$ & $5.59 \pm 0.72 \mathrm{~b}$ & $0.44 \pm 0.05 \mathrm{a}$ & $0.16 \pm 0.02 \mathrm{c}$ \\
$\mathbf{M}_{\mathbf{0}}$ & $\mathbf{T}_{100}$ & $\mathbf{4}$ & $26.82 \pm 2.07 \mathrm{bc}$ & $4.69 \pm 0.89 \mathrm{bc}$ & $0.28 \pm 0.04 \mathrm{~b}$ & $0.34 \pm 0.04 \mathrm{a}$ \\
& $\mathbf{T}_{150}$ & $\mathbf{4}$ & $19.73 \pm 1.41 \mathrm{~cd}$ & $3.22 \pm 0.94 \mathrm{~cd}$ & $0.26 \pm 0.02 \mathrm{~b}$ & $0.28 \pm 0.06 \mathrm{ab}$ \\
\hline & $\mathbf{T}_{\mathbf{0}}$ & $\mathbf{4}$ & $40.47 \pm 5.23 \mathrm{a}$ & $7.50 \pm 0.63 \mathrm{a}$ & $0.46 \pm 0.03 \mathrm{a}$ & $0.19 \pm 0.07 \mathrm{bc}$ \\
& $\mathbf{T}_{50}$ & $\mathbf{4}$ & $26.09 \pm 4.88 \mathrm{bc}$ & $4.24 \pm 0.91 \mathrm{bcd}$ & $0.23 \pm 0.06 \mathrm{~b}$ & $0.22 \pm 0.03 \mathrm{bc}$ \\
$\mathbf{M}_{100}$ & $\mathbf{T}_{100}$ & $\mathbf{4}$ & $28.04 \pm 2.33 \mathrm{~b}$ & $4.46 \pm 0.61 \mathrm{bcd}$ & $0.30 \pm 0.02 \mathrm{~b}$ & $0.21 \pm 0.04 \mathrm{bc}$ \\
& $\mathbf{T}_{150}$ & $\mathbf{4}$ & $18.03 \pm 1.13 \mathrm{~d}$ & $2.97 \pm 0.42 \mathrm{~d}$ & $0.21 \pm 0.01 \mathrm{~b}$ & $0.18 \pm 0.04 \mathrm{bc}$ \\
\hline $\mathbf{P}$ & & & $0.000^{* *}$ & $0.000^{* *}$ & $0.000^{* *}$ & $0.000^{* *}$ \\
\hline $\mathbf{M}_{\mathbf{0}}$ & Ort. & $\mathbf{1 6}$ & $29.78 \pm 8.23$ & $5.43 \pm 2.01$ & $0.38 \pm 0.12$ & $0.23 \pm 0.10$ \\
$\mathbf{M}_{100}$ & Ort. & $\mathbf{1 6}$ & $28.16 \pm 8.97$ & $4.80 \pm 1.82$ & $0.30 \pm 0.11$ & $0.21 \pm 0.47$ \\
\hline $\mathbf{P}$ & & & 0.600 & 0.355 & 0.065 & 0.385 \\
\hline
\end{tabular}

** ile gösterilen $\mathrm{F}$ değerleri \%1 düzeyinde önemlidir.

a,b, c, d : Farklı harflerle gösterilen ortalamalar arasındaki fark \%5 düzeyinde önemlidir.

Çizelge 3. Mikoriza ve tuz uygulamalarının gövde hormon içerikleri üzerine etkisi (ng $\mu \mathrm{L}^{-1}$ )

Table 3. Effect of mycorrhiza and salt applications on steam hormone contents ( $n g \mathrm{LL}^{-1}$ )

\begin{tabular}{|c|c|c|c|c|c|c|}
\hline \multicolumn{2}{|c|}{ Uygulamalar } & $\mathbf{N}$ & GA & SA & IAA & ABA \\
\hline & $T_{0}$ & 4 & $104.66 \pm 3.63 b$ & $21.13 \pm 2.19 a b$ & $1.37 \pm 0.11 \mathrm{a}$ & $0.48 \pm 0.12 c$ \\
\hline & $T_{50}$ & 4 & $100.96 \pm 5.67 b$ & $18.69 \pm 2.57 a b c$ & $1.47 \pm 0.16 a$ & $0.56 \pm 0.15 b c$ \\
\hline \multirow[t]{4}{*}{$M_{0}$} & $\mathbf{T}_{100}$ & 4 & $96.21 \pm 3.94 b c$ & $15.87 \pm 2.75 \mathrm{bcd}$ & $0.91 \pm 0.11 b c$ & $0.89 \pm 0.14 a b$ \\
\hline & $\mathbf{T}_{150}$ & 4 & $75.13 \pm 3.10 \mathrm{~d}$ & $11.58 \pm 2.83 \mathrm{~d}$ & $1.01 \pm 0.07 \mathrm{~b}$ & $0.96 \pm 0.23 a$ \\
\hline & $\mathrm{T}_{0}$ & 4 & $122.42 \pm 6.59 a$ & $23.89 \pm 2.53 a$ & $1.45 \pm 0.17 a$ & $0.55 \pm 0.17 b c$ \\
\hline & $T_{50}$ & 4 & $88.61 \pm 2.82 c$ & $15.12 \pm 2.44 \mathrm{bcd}$ & $0.79 \pm 0.11 b c$ & $0.75 \pm 0.13 a b c$ \\
\hline \multirow[t]{2}{*}{$\mathbf{M}_{100}$} & $T_{100}$ & 4 & $72.26 \pm 8.85 d$ & $12.90 \pm 3.99 \mathrm{~cd}$ & $0.78 \pm 0.09 b c$ & $0.71 \pm 0.05 a b c$ \\
\hline & $\mathbf{T}_{150}$ & 4 & $60.09 \pm 0.92 e$ & $9.97 \pm 1.85 d$ & $0.71 \pm 0.06 c$ & $0.67 \pm 0.11 \mathrm{abc}$ \\
\hline \multicolumn{2}{|l|}{$\mathbf{P}$} & & $0.000 * *$ & $0.000 * *$ & $0.000 * *$ & $0.001 * *$ \\
\hline $\mathbf{M}_{0}$ & Ort. & 16 & $94.24 \pm 12.39$ & $16.82 \pm 4.34$ & $1.19 \pm 0.27 \mathrm{~A}$ & $0.73 \pm 0.26$ \\
\hline$M_{100}$ & Ort. & 16 & $85.84 \pm 24.72$ & $15.48 \pm 5.93$ & $0.93 \pm 0.33 \mathrm{~B}$ & $0.67 \pm 0.14$ \\
\hline $\mathbf{P}$ & & & 0.234 & 0.470 & $0.020 *$ & 0.477 \\
\hline
\end{tabular}

*ve** ile gösterilen $\mathrm{F}$ değerleri sırasıyla \%5 ve \%1 düzeyinde önemlidir.

a,b, c, d veya A, B: Farklı harflerle gösterilen ortalamalar arasındaki fark $\% 5$ düzeyinde önemlidir.

Bir kimyasal sinyal molekülü olan $A B A$, bitki büyüme ve gelişmesinin düzenlemesinde ve bitki su dengesinin kontrol edilmesinde görev almaktadır (Zhu, 2002). Çalışmadaki bulguları destekler nitelikte $A B A$ düzeyi mikoriza aşılanmış mısır (Danneberg ve ark., 1992), Lotus glaber (Sannazzaro ve ark., 2007) ve soya (Meixner ve ark., 2005) bitkilerinin kök ve sürgünlerinde de artmıştır. Mikoriza ile bitki kökleri arasında oluşan simbiyosis sonucu arginin ve isoflavonoidlerin (Caron, 1989), sitokinin ve gibberellin gibi hormonların sentezinde de artış olmaktadır (Muchovej, 2001). Mikoriza kolonizasyon sırasında bitkideki endojen $A B A$ içeriğini 
artırmaktadır (Ludwig-Müller, 2010). Strese koşullarına maruz kalan mikorizalı bitkilerinin $A B A$ içeriğinde belirlenen artış, muhtemelen bu bitkilerin strese karşı gösterdiği toleransa katkı sağlamaktadır. Çalışmada da belirlendiği gibi $A B A$ içeriği ile GA içeriği arasında negatif bir ilişki bulunmakta olup, $A B A, G A$ biyosentezinde yer alan gen ekspresyonunu azaltarak ve GA katabolizmasını artırarak bu duruma sebep olduğu söylenebilir (MartínRodríguez ve ark., 2015). SA bitkilerde stresi azaltmada ve antioksidan aktiviteyi artırmada önemli bir rol oynamaktadır (Shi ve ark., 2009). Bu çalışmada da SA düzeyi tuz dozlarındaki artışlarla önemli düzeyde azalmış, tüm tuz dozlarında mikoriza uygulanmış bitkilerin SA düzeyleri mikoriza uygulanmamış bitkilerden istatistiksel olarak önemli düzeyde olmasa da daha düşük belirlenmiştir. Prakash ve Prathapasenan (1990), tuz stresinin pirinç yapraklarının IAA konsantrasyonunu önemli düzeyde azalttığını, dışarıdan GA uygulanmasının ise tuz stresinin sebep olduğu IAA miktarındaki azalmayı kısmen engellendiğini bildirmişlerdir. Bulgularda da artan dozlardaki tuz stresinin etkisiyle kök ve gövde dokularının IAA içeriği önemli düzeyde azalmıştır. Ancak mikoriza uygulamasının kök dokularının IAA içeriği üzerine önemli bir etkisi belirlenmezken, gövde dokularının IAA içerikleri mikoriza uygulanmışlarda mikorizasızlara kıyasla istatistiksel olarak önemli düzeyde düşük belirlenmiştir $(P<0.05)$.

\section{Gövde ve Kök Dokularının Toplam Fenolik İçeriği ve Antioksidan Kapasitesi}

Tuz stresi ve mikoriza uygulamasının biber bitkilerinde kök ve gövde dokularının toplam fenolik içerikleri ve toplam antioksidan kapasitesi üzerine etkileri Çizelge 4'te verilmiştir. Önceki çalışmalar ile uyumlu olarak tuz dozlarının artışıla kök ve gövde toplam fenolik bileşik miktarı azalmıştır (Bourgou ve ark., 2010; Ksouri ve ark., 2007; Kıpçak ve ark., 2019). Mikoriza uygulanmış bitkiler tüm tuz dozlarında mikoriza uygulanmamışlardan daha yüksek miktarlarda toplam fenolik bileşik içermiştir.

Çizelge 4. Mikoriza ve tuz uygulamalarının kök ve gövde toplam fenolik içerikleri (mg GAE g ${ }^{-1} \mathrm{TA}$ ) toplam antioksidan kapasitesi ( $\mu \mathrm{mol} \mathrm{TE} \mathrm{g}^{-1} \mathrm{TA}$ ) üzerine etkileri

Table 4. The effects of mycorrhiza and salt applications on root and stem total phenolic contents ( $m g$ GAE $g^{-1} T A$ ) total antioxidant capacity ( $\left.\mu \mathrm{mol} \mathrm{TE}^{-1} \mathrm{TA}\right)$

\begin{tabular}{|c|c|c|c|c|c|c|}
\hline \multirow{2}{*}{\multicolumn{2}{|c|}{ Uygulamalar }} & \multicolumn{3}{|c|}{ Kök } & \multicolumn{2}{|c|}{ Gövde } \\
\hline & & $\mathbf{N}$ & Fenolik & Antioksidan & Fenolik & Antioksidan \\
\hline & $T_{0}$ & 4 & $5.07 \pm 0.89 a$ & $6.69 \pm 0.92 b c$ & $2.53 \pm 0.44 a$ & $3.34 \pm 0.46 b c$ \\
\hline & $T_{50}$ & 4 & $2.72 \pm 0.71 \mathrm{c}$ & $5.70 \pm 0.45 \mathrm{~cd}$ & $1.36 \pm 0.35 c$ & $2.85 \pm 0.22 \mathrm{~cd}$ \\
\hline \multirow{4}{*}{$M_{0}$} & $T_{100}$ & 4 & $2.62 \pm 0.54 c$ & $4.80 \pm 0.28 d$ & $1.31 \pm 0.27 c$ & $2.40 \pm 0.14 d$ \\
\hline & $T_{150}$ & 4 & $2.41 \pm 0.62 c$ & $5.18 \pm 0.38 \mathrm{~cd}$ & $1.20 \pm 0.31 \mathrm{c}$ & $2.59 \pm 0.19 c d$ \\
\hline & $T_{0}$ & 4 & $4.88 \pm 1.07 a b$ & $8.08 \pm 0.85 a b$ & $2.44 \pm 0.53 a b$ & $4.04 \pm 0.42 a b$ \\
\hline & $T_{50}$ & 4 & $5.90 \pm 1.24 a$ & $8.45 \pm 1.08 a$ & $2.95 \pm 0.62 \mathrm{a}$ & $4.22 \pm 0.54 a$ \\
\hline \multirow[t]{2}{*}{$M_{100}$} & $T_{100}$ & 4 & $2.82 \pm 0.69 c$ & $5.53 \pm 0.47 c d$ & $1.41 \pm 0.34 c$ & $2.76 \pm 0.23 c d$ \\
\hline & $T_{150}$ & 4 & $2.92 \pm 0.80 \mathrm{bc}$ & $6.05 \pm 0.43 c d$ & $1.46 \pm 0.40 \mathrm{bc}$ & $3.02 \pm 0.21 \mathrm{~cd}$ \\
\hline \multicolumn{2}{|c|}{$\mathbf{P}$} & & $0.000 * *$ & $0.000 * *$ & $0.000 * *$ & $0.000 * *$ \\
\hline$\overline{M_{0}}$ & Ort. & 16 & $3.21 \pm 1.29$ & $5.60 \pm 0.89 B$ & $1.61 \pm 0.6$ & $2.80 \pm 0.4 \mathrm{~B}$ \\
\hline$M_{100}$ & Ort. & 16 & $4.13 \pm 1.61$ & $7.03 \pm 1.47 \mathrm{~A}$ & $2.07 \pm 0.8$ & $3.52 \pm 0.7 \mathrm{~A}$ \\
\hline \multicolumn{2}{|c|}{$\mathbf{P}$} & & 0.080 & $0.002 * *$ & 0.083 & $0.003^{* *}$ \\
\hline
\end{tabular}

** ile gösterilen $\mathrm{F}$ değerleri \%1 düzeyinde önemlidir.

a,b, c, d veya A, B: Farklı harflerle gösterilen ortalamalar arasındaki fark $\% 5$ düzeyinde önemlidir.

Ancak en yüksek toplam fenolik bileşik miktarı, $50 \mathrm{mM}$ tuz stresi uygulanmış mikorizalı bitkilerin kök ve gövde dokularında sırası ile 5.90 ve $2.95 \mathrm{mg} \mathrm{GAE} \mathrm{g}^{-1}$ TA olarak belirlenmiştir. Fenolik bileşikler lipid alkoksil radikallerini yakalayarak lipid peroksidasyonunu inhibe edebilmekte (Michalak, 2006) ve serbest radikallere hidrojen vererek onları daha zararsız hale getirebilmektedir (Es-Safi ve ark., 2007). Yapılan araştırmalar fenolik bileşiklerin bitki hücrelerinde hidrojen peroksit $\left(\mathrm{H}_{2} \mathrm{O}_{2}\right)^{\prime} \mathrm{i}$ etkisiz hale getirdiğini de bildirmektedir (Takahama ve Oniki, 1997). Çalışmada bulunan sonuçları destekler nitelikte birçok araştırmada mikoriza uygulamasının toplam fenolik bileşik miktarını artırdığı bildirilmiştir (Orujei ve ark., 2013; Dutt ve ark., 2013).

Toplam antioksidan kapasitesi mikorizalı ve mikorizasız bitkilerde artan tuz dozlarının etkisiyle azalmış, ancak 0 ve $50 \mathrm{mM}$ tuz uygulanmış mikorizalı bitkilerde mikoriza uygulanmamışlara kıyasla önemli düzeyde artış 
göstermiştir. Yüksek tuz dozlarında (100 ve $150 \mathrm{mM}$ ) ise mikorizalı ve mikorizasız bitkilerin toplam antioksidan kapasiteleri arasında önemli bir fark belirlenmemiştir. Tüm uygulamalar içerisinde gerek kök gerekse de gövde dokularında en yüksek toplam antioksidan kapasitesi 50 $\mathrm{mM}$ tuz dozunda sırasıyla 8.45 ve $4.22 \mu \mathrm{mol} \mathrm{TE} \mathrm{g}^{-1}$ TA olarak belirlenmiştir. $\mathrm{Bu}$ durum ılımlı tuzluluk koşullarında mikorizanın stres koşullarını iyileştirdiği şeklinde yorumlanabilir. Shams ve ark. (2016), toplam fenolik içeriği ve antioksidan kapasitesinin tuz stresinin etkisiyle marulda önemli düzeyde azaldığını bildirmişlerdir. Ancak tuz stresi altındaki bitkilerde fenolik bileşiklerin üretimi, bitkilerin tuza duyarlılığına bağlı olarak değişim gösterebilmektedir (Kim ve ark., 2008). Yüksek tuz dozlarında mikorizal simbiyoz oluşumunun olumsuz etkilendiği birçok araştırmacı tarafından bildirilmektedir (Juniper ve Abbott 1993;
McMillen ve ark., 1998; Wang ve ark., 2018). Dolayısı ile toplam fenolik bileşik ve antioksidan kapasitede 100 ve $150 \mathrm{mM}$ tuz dozlarında mikorizanın olumlu etkisinin belirlenmemesinin sebebi, yüksek tuzdan dolayı mikoriza kolonizasyonunun azalması olabilir.

\section{Gövde ve Kök Dokularının Organik Asit Içerikleri}

Biber bitkilerine uygulanan tuz dozlarındaki artış ile kök ve gövde dokularının organik asit içerikleri (gövde tartarik ve maleik asit ile kök maleik asit hariç) kontrol bitkilerine kıyasla artmıştır. Mikoriza uygulanmış bitkiler de ise; gövde bütirik, malonik ve malik asit içerikleri mikoriza uygulanmamışlardan daha yüksek belirlenirken, kök dokularında malonik ve malik asit içerikleri mikorizalı olanlarda daha yüksek belirlenmiştir (Çizelge 5 ve 6).

Çizelge 5. Mikoriza ve tuz uygulamalarının kök organik asit içerikleri üzerine etkisi (ng $\mu^{-1}$ )

Table 5. Effects of mycorrhiza and salt applications on root organic acid contents ( $n g \mu L^{-1}$ )

\begin{tabular}{|c|c|c|c|c|c|c|c|}
\hline \multicolumn{2}{|c|}{ Uygulamalar } & $\mathbf{N}$ & Okzalik & Propiyonik & Tartarik & Bütirik & Malonik \\
\hline \multirow{4}{*}{$M_{0}$} & $T_{0}$ & 4 & $0.15 \pm 0.03 c$ & $0.63 \pm 0.03 b c$ & $2.05 \pm 0.46 a b$ & $3.51 \pm 0.20 d$ & $4.01 \pm 0.43 d$ \\
\hline & $\mathbf{T}_{50}$ & 4 & $0.30 \pm 0.11 \mathrm{abc}$ & $0.84 \pm 0.16 b$ & $1.95 \pm 0.20 \mathrm{ab}$ & $4.43 \pm 0.63 \mathrm{bcd}$ & $4.48 \pm 0.70 \mathrm{bcd}$ \\
\hline & $\mathrm{T}_{100}$ & 4 & $0.36 \pm 0.10 \mathrm{ab}$ & $0.65 \pm 0.05 b c$ & $2.65 \pm 1.06 a$ & $6.01 \pm 0.65 a$ & $5.91 \pm 0.79 a b$ \\
\hline & $\mathrm{T}_{150}$ & 4 & $0.21 \pm 0.04 b c$ & $0.61 \pm 0.09 b c$ & $1.63 \pm 0.15 a b$ & $3.83 \pm 0.23 d$ & $4.20 \pm 0.37 \mathrm{~cd}$ \\
\hline \multirow{4}{*}{$M_{100}$} & $\mathrm{~T}_{0}$ & 4 & $0.11 \pm 0.02 c$ & $0.50 \pm 0.07 c$ & $1.51 \pm 0.25 b$ & $5.36 \pm 0.50 \mathrm{ab}$ & $6.62 \pm 0.83 a$ \\
\hline & $\mathbf{T}_{50}$ & 4 & $0.12 \pm 0.02 c$ & $0.52 \pm 0.10 c$ & $1.59 \pm 0.35 a b$ & $4.16 \pm 0.67 \mathrm{~cd}$ & $5.47 \pm 0.67 \mathrm{abcd}$ \\
\hline & $\mathrm{T}_{100}$ & 4 & $0.46 \pm 0.17 a$ & $1.22 \pm 0.17 a$ & $2.56 \pm 0.27 a b$ & $5.09 \pm 0.38 \mathrm{abc}$ & $4.89 \pm 0.37 \mathrm{bcd}$ \\
\hline & $\mathrm{T}_{150}$ & 4 & $0.30 \pm 0.08 a b c$ & $0.83 \pm 0.11 b$ & $1.96 \pm 0.28 \mathrm{ab}$ & $4.34 \pm 0.28 \mathrm{bcd}$ & $5.61 \pm 0.66 a b c$ \\
\hline \multicolumn{2}{|c|}{$\mathbf{P}$} & & $0.000^{* *}$ & $0.000 * *$ & $0.012 * *$ & $0.000 * *$ & $0.000 * *$ \\
\hline$M_{0}$ & Ort. & 16 & $0.26 \pm 0.11$ & $0.68 \pm 0.13$ & $2.07 \pm 0.65$ & $4.45 \pm 1.08$ & $4.65 \pm 0.94 B$ \\
\hline$M_{100}$ & Ort. & 16 & $0.25 \pm 0.17$ & $0.77 \pm 0.32$ & $1.91 \pm 0.50$ & $4.74 \pm 0.67$ & $5.65 \pm 0.87 A$ \\
\hline \multicolumn{2}{|c|}{$\mathbf{P}$} & & 0.905 & 0.308 & 0.435 & 0.367 & $0.004 * *$ \\
\hline
\end{tabular}

\begin{tabular}{|c|c|c|c|c|c|c|c|c|}
\hline \multicolumn{2}{|c|}{ Uygulamalar } & \multirow{2}{*}{$\frac{N}{4}$} & \multirow{2}{*}{$\begin{array}{l}\text { Malik } \\
0.96 \pm 0.02 d\end{array}$} & \multirow{2}{*}{$\begin{array}{l}\text { Laktik } \\
7.59 \pm 0.92 \mathrm{c}\end{array}$} & \multirow{2}{*}{$\begin{array}{l}\text { Sitrik } \\
26.56 \pm 0.39 c d\end{array}$} & \multirow{2}{*}{$\begin{array}{l}\text { Maleik } \\
12.28 \pm 0.55\end{array}$} & \multirow{2}{*}{$\begin{array}{l}\text { Fumarik } \\
7.35 \pm 0.85 b c\end{array}$} & \multirow{2}{*}{$\begin{array}{l}\text { Suksinik } \\
55.54 \pm 9.09 b c\end{array}$} \\
\hline & $T_{0}$ & & & & & & & \\
\hline & $T_{50}$ & 4 & $1.24 \pm 0.15 \mathrm{bcd}$ & $9.46 \pm 1.01 \mathrm{abc}$ & $27.75 \pm 1.26 b c$ & $14.83 \pm 2.50$ & $11.57 \pm 1.87 a$ & $64.83 \pm 2.70 \mathrm{abc}$ \\
\hline \multirow[t]{4}{*}{$\mathbf{M}_{0}$} & $T_{100}$ & 4 & $1.43 \pm 0.05 a b$ & $12.65 \pm 1.32 \mathrm{a}$ & $24.05 \pm 0.79 \mathrm{e}$ & $14.18 \pm 3.39$ & $9.36 \pm 1.28 \mathrm{abc}$ & $53.81 \pm 1.61 c$ \\
\hline & $\mathrm{T}_{150}$ & 4 & $1.12 \pm 0.12 \mathrm{~cd}$ & $9.49 \pm 1.76 a b c$ & $25.12 \pm 0.74 \mathrm{de}$ & $13.13 \pm 2.95$ & $9.27 \pm 1.07 \mathrm{abc}$ & $57.38 \pm 2.42 \mathrm{abc}$ \\
\hline & $T_{0}$ & 4 & $1.41 \pm 0.06 \mathrm{abc}$ & $10.72 \pm 2.36 \mathrm{abc}$ & $23.68 \pm 0.95 \mathrm{e}$ & $10.99 \pm 0.33$ & $6.97 \pm 0.55 c$ & $60.05 \pm 6.10 a b c$ \\
\hline & $T_{50}$ & 4 & $1.36 \pm 0.12 \mathrm{abc}$ & $8.95 \pm 0.64 b c$ & $25.23 \pm 1.36 \mathrm{de}$ & $11.46 \pm 1.08$ & $7.28 \pm 0.56 b c$ & $53.44 \pm 6.42 c$ \\
\hline \multirow[t]{2}{*}{$M_{100}$} & $T_{100}$ & 4 & $1.47 \pm 0.15 \mathrm{ab}$ & $10.31 \pm 1.67 a b c$ & $29.05 \pm 0.77 a b$ & $14.93 \pm 2.29$ & $11.66 \pm 1.92 \mathrm{a}$ & $66.20 \pm 3.36 a b$ \\
\hline & $\mathrm{T}_{150}$ & 4 & $1.55 \pm 0.20 a$ & $12.15 \pm 1.65 \mathrm{ab}$ & $30.53 \pm 0.51 a$ & $15.26 \pm 3.44$ & $9.94 \pm 0.79 \mathrm{ab}$ & $68.88 \pm 3.66 \mathrm{a}$ \\
\hline \multicolumn{2}{|c|}{$\mathbf{P}$} & & $0.000 * *$ & $0.002 * *$ & $0.000 * *$ & 0.104 & $0.000 * *$ & $0.001 * *$ \\
\hline$M_{0}$ & Ort. & 16 & $1.19 \pm 0.20 B$ & $9.80 \pm 2.21$ & $25.87 \pm 1.64$ & $13.61 \pm 2.53$ & $9.39 \pm 1.95$ & $57.89 \pm 6.21$ \\
\hline$M_{100}$ & Ort. & 16 & $1.45 \pm 0.15 \mathrm{~A}$ & $10.54 \pm 1.92$ & $27.13 \pm 2.99$ & $13.16 \pm 2.78$ & $8.97 \pm 2.24$ & $62.15 \pm 7.65$ \\
\hline \multicolumn{2}{|c|}{$\mathbf{P}$} & & $0.000 * *$ & 0.324 & 0.151 & 0.637 & 0.570 & 0.094 \\
\hline
\end{tabular}

** ile gösterilen $\mathrm{F}$ değerleri \%1 düzeyinde önemlidir.

a,b, c, d veya A, B: Farklı harflerle gösterilen ortalamalar arasındaki fark $\% 5$ düzeyinde önemlidir.

Shams ve ark. (2016), marul bitkisine uygulanan 100 mM'lık tuz stresinin bütirik, malik, maleik ve suksinik asit içeriklerini etkilemezken, okzalik, propiyonik, tartarik, laktik, sitrik ve fumarik asit içeriklerini artırdığını bildirmişlerdir. Sheng ve ark. (2011), uygulanan tüm tuz dozlarında oksalik, fumarik, asetik, malik ve sitrik asit konsantrasyonlarının mikorizalı bitkilerde mikorizasızlardan yüksek belirlendiğini, ancak malik ve 
sitrik asit konsantrasyonları üzerine mikoriza uygulamasının etkisi 0.5 ve $1.0 \mathrm{~g} \mathrm{~kg}^{-1} \mathrm{NaCl}$ dozlarında önemsiz belirlendiğini bildirmişlerdir. Zhang ve ark. (2003), mikoriza kolonizasyonunun kök salgılarındaki organik asit içeriklerini değiştirebileceğini, bunun toprak $\mathrm{pH}^{\prime}$ sını, EC değerini ve organik karbon içeriğini azaltabileceğini ayrıca $\mathrm{N}, \mathrm{P}$ ve $\mathrm{K}^{\prime}$ ın topraktan alına bilirliğinde bir artış meydana getirebileceğini bildirmiştir (Dinkelaker ve ark., 1997; Usha ve ark., 2004). Okzalik, propiyonik ve tartarik asit savunma organik asitleri olarak kabul edilmekte olup, stres koşullarında sinyal görevi göstermenin yanı sıra, mineral maddelerin hücre içerisinde dengesinin sağlanmasında, savunma amino asitlerinin sentezinde ve osmotik dengenin sağlanmasında rol oynamaktadırlar (Walker ve ark.,
2003; Rivas-Ubach ve ark., 2012). Bütirik asit prolin sentezini teşvik ederek (Zolman ve ark., 2008), malonik asit ve malik asit bitki ozmotik potansiyelini ayarlayarak (Greene ve ark., 1993; Egle ve ark., 2003), laktik asit savunma sistemini uyararak (Gupta ve ark., 2016), sitrik asit antioksidan savunma sistemini uyararak (Iwasaki ve ark., 2011), maleik asit enzim aktivitelerini ayarlayarak (Cawthray, 2003) bitkilerin stres koşullarına toleransını artııılar ve stres koşullarında seviyelerinde artış meydana gelmektedir. Tuz stresi altındaki bitkilerde organik asitlerin artışı, hücresel makro molekülleri stabilize ederek ozmotik dengeyi korur ve stres sebebiyle üretilen serbest radikalleri nötralize eder (Sneha ve ark., 2013).

Çizelge 6. Mikoriza ve tuz uygulamalarının gövde organik asit içerikleri üzerine etkisi ( $\mathrm{ng} \mu \mathrm{L}^{-1}$ )

Table 6. Effect of mycorrhiza and salt applications on body organic acid contents ( $n g \mu L^{-1}$ )

\begin{tabular}{|c|c|c|c|c|c|c|c|}
\hline \multicolumn{2}{|c|}{ Uygulamalar } & \multirow{2}{*}{$\begin{array}{l}N \\
4\end{array}$} & \multirow{2}{*}{$\begin{array}{l}\text { Okzalik } \\
0.33 \pm 0.12 b\end{array}$} & \multirow{2}{*}{$\begin{array}{l}\text { Propiyonik } \\
1.61 \pm 0.05 d\end{array}$} & \multirow{2}{*}{$\begin{array}{l}\text { Tartarik } \\
5.37 \pm 0.82\end{array}$} & \multirow{2}{*}{$\begin{array}{l}\text { Bütirik } \\
12.71 \pm 1.03 d\end{array}$} & \multirow{2}{*}{$\begin{array}{l}\text { Malonik } \\
14.12 \pm 0.85 \mathrm{e}\end{array}$} \\
\hline & $\mathrm{T}_{0}$ & & & & & & \\
\hline & $T_{50}$ & 4 & $1.01 \pm 0.32 \mathrm{a}$ & $2.78 \pm 0.40 \mathrm{ab}$ & $6.52 \pm 0.55$ & $15.14 \pm 0.85 b c$ & $15.31 \pm 1.02 \mathrm{cde}$ \\
\hline \multirow[t]{4}{*}{$\mathbf{M}_{0}$} & $T_{100}$ & 4 & $1.08 \pm 0.22 \mathrm{a}$ & $2.32 \pm 0.12 b c$ & $6.63 \pm 0.25$ & $15.37 \pm 0.73 b c$ & $15.11 \pm 1.12 \mathrm{de}$ \\
\hline & $\mathrm{T}_{150}$ & 4 & $0.71 \pm 0.19 a b$ & $2.09 \pm 0.32 \mathrm{~cd}$ & $5.61 \pm 0.62$ & $12.78 \pm 0.24 d$ & $14.01 \pm 0.51 \mathrm{e}$ \\
\hline & $T_{0}$ & 4 & $0.31 \pm 0.11 b$ & $1.66 \pm 0.10 d$ & $5.50 \pm 0.96$ & $13.73 \pm 0.39 c d$ & $16.95 \pm 1.02 \mathrm{bcd}$ \\
\hline & $T_{50}$ & 4 & $0.39 \pm 0.37 b$ & $1.79 \pm 0.06 c d$ & $5.65 \pm 0.45$ & $13.83 \pm 1.55 \mathrm{~cd}$ & $18.19 \pm 1.38 \mathrm{ab}$ \\
\hline \multirow[t]{2}{*}{$M_{100}$} & $T_{100}$ & 4 & $1.18 \pm 0.36 a$ & $3.12 \pm 0.23 a$ & $6.57 \pm 0.40$ & $18.19 \pm 1.11 \mathrm{a}$ & $17.55 \pm 1.44 \mathrm{abc}$ \\
\hline & $\mathrm{T}_{150}$ & 4 & $1.01 \pm 0.23 a$ & $2.79 \pm 0.25 \mathrm{ab}$ & $6.51 \pm 0.71$ & $16.40 \pm 0.50 \mathrm{ab}$ & $19.87 \pm 0.18 a$ \\
\hline \multicolumn{2}{|c|}{$\mathbf{P}$} & & $0.000 * *$ & $0.000 * *$ & 0.069 & $0.000 * *$ & $0.000 * *$ \\
\hline$M_{0}$ & Ort. & 16 & $0.79 \pm 0.36$ & $2.21 \pm 0.50$ & $6.03 \pm 0.78$ & $14.01 \pm 1.47 \mathrm{~B}$ & $14.64 \pm 1.01 B$ \\
\hline$M_{100}$ & Ort. & 16 & $0.72 \pm 0.44$ & $2.35 \pm 0.67$ & $6.06 \pm 0.78$ & $15.54 \pm 2.13 \mathrm{~A}$ & $18.14 \pm 1.51 \mathrm{~A}$ \\
\hline \multicolumn{2}{|c|}{$\mathbf{P}$} & & 0.650 & 0.509 & 0.909 & $0.024^{*}$ & $0.000 * *$ \\
\hline
\end{tabular}

\begin{tabular}{|c|c|c|c|c|c|c|c|c|}
\hline \multicolumn{2}{|c|}{ Uygulamalar } & \multirow{2}{*}{$\frac{N}{4}$} & \multirow{2}{*}{$\begin{array}{l}\text { Malik } \\
3.38 \pm 0.21 \mathrm{~d}\end{array}$} & \multirow{2}{*}{$\begin{array}{l}\text { Laktik } \\
26.92 \pm 1.92 c\end{array}$} & \multirow{2}{*}{$\begin{array}{l}\text { Sitrik } \\
13.28 \pm 0.19 \mathrm{~cd}\end{array}$} & \multirow{2}{*}{$\begin{array}{l}\text { Maleik } \\
6.14 \pm 0.27\end{array}$} & \multirow{2}{*}{$\begin{array}{l}\text { Fumarik } \\
3.67 \pm 0.42 b c\end{array}$} & \multirow{2}{*}{$\begin{array}{l}\text { Suksinik } \\
27.77 \pm 4.54 b c\end{array}$} \\
\hline & $\mathrm{T}_{0}$ & & & & & & & \\
\hline & $T_{50}$ & 4 & $4.27 \pm 0.26 b c$ & $32.60 \pm 4.51 b c$ & $13.87 \pm 0.63 b c$ & $7.41 \pm 1.25$ & $5.78 \pm 0.93 a$ & $32.41 \pm 1.35 a b c$ \\
\hline \multirow[t]{4}{*}{$\mathbf{M}_{0}$} & $T_{100}$ & 4 & $4.12 \pm 0.15 b c$ & $32.39 \pm 1.45 b c$ & $12.02 \pm 0.39 e$ & $7.09 \pm 1.69$ & $4.68 \pm 0.64 a b c$ & $26.90 \pm 0.81 c$ \\
\hline & $\mathbf{T}_{150}$ & 4 & $3.74 \pm 0.30 \mathrm{bcd}$ & $31.53 \pm 4.67 b c$ & $12.56 \pm 0.37 \mathrm{de}$ & $6.56 \pm 1.47$ & $4.63 \pm 0.53 a b c$ & $28.69 \pm 1.21 \mathrm{abc}$ \\
\hline & $\mathrm{T}_{0}$ & 4 & $3.62 \pm 0.18 \mathrm{~cd}$ & $27.33 \pm 4.74 b c$ & $11.84 \pm 0.47 \mathrm{e}$ & $5.49 \pm 0.16$ & $3.48 \pm 0.27 c$ & $30.02 \pm 3.05 a b c$ \\
\hline & $\mathbf{T}_{50}$ & 4 & $4.39 \pm 0.30 b$ & $29.85 \pm 1.27 b c$ & $12.61 \pm 0.68 \mathrm{de}$ & $5.73 \pm 0.54$ & $3.64 \pm 0.28 b c$ & $26.72 \pm 3.21 c$ \\
\hline \multirow[t]{2}{*}{$M_{100}$} & $\mathrm{~T}_{100}$ & 4 & $5.18 \pm 0.37 a$ & $35.22 \pm 2.90 \mathrm{ab}$ & $14.52 \pm 0.38 \mathrm{ab}$ & $7.46 \pm 1.14$ & $5.83 \pm 0.96 a$ & $33.10 \pm 1.68 a b$ \\
\hline & $\mathrm{T}_{150}$ & 4 & $5.33 \pm 0.42 a$ & $41.60 \pm 3.66 a$ & $15.26 \pm 0.25 a$ & $7.63 \pm 1.72$ & $4.97 \pm 0.39 a b$ & $34.44 \pm 1.83 a$ \\
\hline \multicolumn{2}{|c|}{$\mathbf{P}$} & & $0.000 * *$ & $0.000 * *$ & $0.000 * *$ & 0.104 & $0.000 * *$ & $0.001 * *$ \\
\hline Mo & Ort. & 16 & $3.88 \pm 0.42 B$ & $30.87 \pm 3.91$ & $12.94 \pm 0.82$ & $6.81 \pm 1.26$ & $4.70 \pm 0.97$ & $28.94 \pm 3.10$ \\
\hline$M_{100}$ & Ort. & 16 & $4.63 \pm 0.77 \mathrm{~A}$ & $33.50 \pm 6.42$ & $13.56 \pm 1.49$ & $6.58 \pm 1.39$ & $4.48 \pm 1.11$ & $31.07 \pm 3.82$ \\
\hline \multicolumn{2}{|c|}{$\mathbf{P}$} & & 0.002 & 0.171 & 0.137 & 0.473 & 0.440 & 0.078 \\
\hline
\end{tabular}

*ve** ile gösterilen $\mathrm{F}$ değerleri sırasıyla \%5 ve \%1 düzeyinde önemlidir.

$a, b, c, d$ veya A, B: Farklı harflerle gösterilen ortalamalar arasındaki fark $\% 5$ düzeyinde önemlidir.

Bu çalışmada dikkat çeken sonuçlar $50 \mathrm{mM}$ tuz uygulanmış mikorizalı $\left(\mathrm{M}_{100} \mathrm{~T}_{50}\right)$ bitkilerde belirlenmiştir. $\mathrm{M}_{100} \mathrm{~T}_{50}$ uygulaması yapılmış biber bitkilerinin kök ve gövde dokularında; okzalik, propiyonik, sitrik, fumarik asit içeriklerinde mikorizasız bitkilere kıyasla önemli düzeyde azalma tespit edilirken, malonik ve malik asit içeriğinde artış belirlenmiştir. Tartarik, bütirik, malik, laktik, maleik ve suksinik asit içerikleri ise $50 \mathrm{mM}$ tuz uygulanmış mikorizalı ve mikorizasız bitkilerde etkilenmemiştir. Her ne kadar $50 \mathrm{mM}$ tuz uygulanmış mikorizalı bitkilerin organik asit içerikleri (malonik ve malik asit hariç) aynı tuz dozundaki mikorizasız 
bitkilerden daha düşük belirlenmiş olmasına karşılık, 100 ve $150 \mathrm{mM}$ tuz uygulanmış mikorizalı bitkilerde mikorizasızlara kıyasla organik asit içeriklerinde istatistiksel olarak önemli düzeyde artışlar belirlenmiştir (Çizelge 5 ve 6). Gövde ve kök dokularının organik asit içeriklerinde $M_{100} T_{50}$ uygulamasında görülen bu durumun, aynı uygulamada belirlenen yüksek $A B A$, toplam fenolik bileşik ve toplam antioksidan kapasitesi ile ilişkili olduğu düşünülmektedir.

Bütün bu sonuçlardan, $50 \mathrm{mM}$ tuz uygulanmış mikorizalı bitkilerde mikorizasızlara kıyasla önemli düzeyde yüksek belirlenen; $A B A$, toplam fenolik bileşik ve toplam antioksidan kapasitesi bitkide tuza karşı tolerans sağlayabildiği için organik asitlerin düzeylerinde artış meydana gelmemekte ancak, daha yüksek tuz dozlarında bu parametrelerde meydana gelen düşüşten dolayı strese karşı koruyucu etkisinin azaldığı ve devreye organik asit içeriğindeki artışın girdiği öne sürülebilir.

Sonuç olarak; elde edilen veriler ılımlı tuzluluk olarak adlandırabileceğimiz, 50 mM'lık tuzluluk koşulları (ılımlı tuzluluk koşulları) altındaki biber bitkisine yapılan mikoriza aşılamasının, bitkilerin stres koşullarına toleransını artıran; ABA, toplam fenolik bileşik ve toplam antioksidan kapasitesini artırmak sureti ile katkı sağladığını göstermektedir. Yüksek tuz dozlarında ise mikoriza uygulamasının organik asit içerikleri hariç hormon, toplam fenolik ve antioksidan içerikleri üzerinde olumlu bir etkisi belirlenmemiştir. Stres koşullarında artış gösteren organik asit içeriklerinin, malonik ve malik asit hariç, $50 \mathrm{mM}$ tuz dozunda mikorizalılarda mikorizasızlara kıyasla daha düşük ancak yüksek tuzluluk koşullarını temsil eden 100 ve 150 mM tuz dozlarında ise daha yüksek belirlenmesi, tuza karşı toleransta $50 \mathrm{mM}$ 'dan sonraki tuz dozlarının mikorizanın karşı koyamadığı şeklinde yorumlanmıştır.

Sonuç olarak mikorizanın özellikle $50 \mathrm{mM}$ tuz dozuna kadarki strese karşı tolerans göstermede etkili olduğu, ancak daha yüksek tuz konsantrasyonlarında bu olumlu etkinin gerçekleşmediği belirlenmiştir.

\section{ÖZET}

Amaç: Çalışmada, mikoriza (ROOTS-novozymes endomycorrhiza (VAM) fungus (Glomus spp.)) ve artan tuz dozlarının biber bitkisinin (Capsicum annuum L.) kök ve gövde dokularının; hormon, toplam fenolik ve organik asit içerikleri ile toplam antioksidan kapasitesi üzerine etkisini belirlemek amaçlanmıştır.

Yöntem ve Bulgular: Serada tesadüf blokları deneme deseninde göre yürütülen çalışmada, toprak doldurulmuş saksılardaki biber bitkilerine dört farklı dozda tuz (To: 0, $T_{50}: 50, T_{100}: 100$ ve $T_{150}: 150 \mathrm{mM} \mathrm{NaCl}$ ) ile mikorizalı ve mikorizasız olmak üzere mikorizanın iki dozu ( $\mathrm{M}_{0}$ : 0, $\mathrm{M}_{100}$ : 100 adet spor/bitki) uygulanmıştır. Çalışmada, kök ve gövde dokularında giberilik asit (GA), salisilik asit (SA) ve indol asetik asit (IAA) düzeyleri artan tuz dozlarının etkisiyle istatistiksel olarak önemli düzeyde azalmıştır. Biber bitkisi absisik asit ( $A B A$ ) içeriği mikoriza uygulanmamış bitkilerin kök ve gövde dokularında tuz dozlarındaki artış ile önemli düzeyde artmışken, mikoriza uygulanan bitkilerde tuz dozlarındaki artış ABA içerini etkilememiştir. Sadece 50 $\mathrm{mM}$ tuz dozunda belirlenen $A B A$ içeriği mikoriza uygulanmışlarda mikorizasızlara göre önemli düzeyde daha yüksek belirlenmiştir. Toplam fenolik içeriği ve antioksidan kapasitesi tuz stresinin etkisiyle kök ve gövde dokularında önemli düzeyde azalmışken, $50 \mathrm{mM} \mathrm{NaCl}$ uygulanmış mikorizalı bitkilerde en yüksek değerde belirlenmiştir. Organik asit içerikleri, gövde tartarik ve maleik asit ile kök maleik asit hariç, uygulanan tuz dozlarındaki artış ile kök ve gövde dokularında kontrol bitkilerine göre artmıştır. Mikoriza uygulanmış bitkilerin gövde bütirik, malonik ve malik asit içerikleri mikoriza uygulanmamışlar daha yüksek belirlenmişken, kök dokularında ise malonik ve malik asit içerikleri mikorizalı olanlarda daha yüksek belirlenmiştir.

Genel Yorum: Mikorizanın özellikle $50 \mathrm{mM}$ tuz dozunda gövde ve kök dokularında toplam fenolik ve antioksidan içeriklerinin yanı sıra ABA düzeyini arttırmasından dolayı strese karşı tolerans göstermede etkili olduğu, ancak daha yüksek tuz konsantrasyonlarında bu olumlu etkisinin bozulduğu belirlenmiştir.

Çalışmanın Önemi ve Etkisi: Sonuç olarak, mikorizanın ılımlı tuz stresinde bitki toleransını arttırdığı ancak, yüksek ve çok yüksek tuz tuz streslerinde etkisiz kaldığı söylenebilir.

Anahtar Kelimeler: Mikoriza, tuz stresi, hormon, fenolik, antioksidan, organik asit.

\section{ÇIKAR ÇATIŞMA BEYANI}

Makale yazarları aralarında herhangi bir çıkar çatışması olmadığını beyan ederler.

\section{ARAŞTIRMACILARIN KATKI ORANI BEYANI}

Yazarlar makaleye eşit oranda katkı sağlamış olduklarını beyan ederler.

\section{KAYNAKLAR}

Allison LE, Moodie CD (1965) Carbonate. In: Method of Soil Analysis, Part 2 (Ed. Black CA), American Society of Agronomy, Inc. Madison, Winconsin, USA, pp 1379-1396. 
Altunlu H (2019) The effects of mycorrhiza application on growth and antioxidative enzymes of capia type pepper (Capsicum annuum L.) seedling under salty conditions, Ege Uni. Zir. Fak. Derg. 56(2): 139-146.

Anonim (2018) Tuzlu ve Alkali Alanlarda Kullanılabilecek Bazı Bitki Türlerinin Tespiti ve Adaptasyonu Projesi Sonuç Raporu, T.C. Tarım ve Orman Bakanlığı Çölleşme ve Erozyonla Mücadele Genel Müdürlüğü, https://www.tarimorman.gov.tr/CEM/Belgeler/yay\% C4\%B1nlar/yay\%C4\%B1nlar\%202019/KIRSEHIR\%20T uzlu\%20Alkali\%20Sonuc\%20Raporu\%20.pdf (Erişim tarihi: 18 Eylül 2020)

Ashraf M (1994) Breeding for salinity tolerance in plants. Crit. Rev. Plant Sci. 13: 17-42.

Ashraf MY, Bhatti AS (2000) Effect of salinity on growth and chlorophyll content in rice. Pakistan J. Sci. Ind. Res. 43(2): 130-131.

Başak H, Kasım R, Okay FY (2011) The effect of endomycorrhiza (VAM) treatment on growth of tomato seedling grown under saline conditions. African J. Agri. Res. 6(11): 2532-2538.

Bourgou S, Kchouk ME, Bellila A, Marzouk B (2010) Effect of salinity on phenolic composition and biological activity of Nigella sativa. Acta Horticulturae 853: 5760.

Bouyoucos GD (1951) A recablibration of the hydrometer method for making mechanical analysis of the soil. Agronomy Journal 43: 434-38.

Bremner JM (1996) Nitrogen total, In: Methods of Soil Analysis Part 3-Chemical Methods (Eds. Sparks DL), SSSA Book Series Number 5, SSSA. Madison, WI, pp 1085-112.

Caron M (1989) Potential use of mycorrhizae in control of soil-borne diseases. Canad J. Plant Pathol. 11: 177179.

Carvalho LM, Correia PM, Martins-Louçao AM (2004) Arbuscular mycorrhizal fungal propogules in a salt marsh. Mycorrhiza 14: 165-170.

Cawthray GR (2003) An improved reversed-phase liquid chromatographic method of the analysis of lowmolecular mass organic acids in plant root exudates. J. Chromatogr. A. 1011(12): 233-240.

Colla G, Rouphael Y, Cardarelli M, Tullio M, Rivera CM, Rea E (2008) Alleviation of salt stress by arbuscular mycorrhizal in zucchini plants grown at low and high phosphorus concentration. Biol. Fertil. Soils 44(3): 501-509.

Danneberg G, Latus C, Zimmer W, Hundeshagen B, Schneider-Poetsch HJ, Bothe H (1992) Influence of vesicular-arbuscular mycorrhiza on phytohormone balances in maize (Zea mays L.). J. Plant Physiol. 141: 33-39.
Davies PJ (1995) The plant hormones; Their nature, occurence and functions, In: Plant Hormones (Ed. Davies PJ) Kluwer Academic Publishers, Boston. pp 139.

Dinkelaker B, Hengeler G, Neumann G, Eltrop L, Marschner H (1997) Root exudates and mobilization of nutrients. In: Trees-contributions to modern tree physiology (Eds. Rennenberg H, Eschrich W, Ziegler H), Backhuys, Leiden. pp 441-452.

Dutt S, Sharma SD, Kumar P (2013) Arbuscular mycorrhizas and $\mathrm{Zn}$ fertilization modify growth and physiological behavior of apricot (Prunus armeniaca L.). Scientia Horticulturae 155: 97-104.

Düzgüneş O, Kesici T, Kavuncu O, Gürbüz $F$ (1987) Araştırma ve Deneme Metotları. Ankara Üni., Ziraat Fakültesi Yayınları, Ankara, 381s.

Egle K, Romer W, Keller H (2003) Exudation of low molecular weight organic acids by Lupinus albus L., Lupinus angustifolius L. and Lupinus luteus L. as affected by phosphorus supply. Agronomie 23: 511518.

Emirzeoğlu C, Başak H (2020) Orta Anadolu biber genotiplerinin farklı tuz konsantrasyonlarına tolerans düzeylerinin belirlenmesi. Uluslararası Tarım ve Yaban Hayatı Bil. Derg. 6(2): 129-140.

Es-Safi NE, Kollman A, Khlifi S, Ducrot PH (2007) Antioxidative effect of compounds isolated from Globularia alypum L. structure-activity relationship. LWT. 40: 1246-1252.

Greene JG, Porter RH, Eller RV, Greenamyre JT (1993) Inhibition of succinate dehydrogenase by malonic acid produces an 'excitotoxic' lesion in rat striatum. Neurochemistry 61: 1151-1154.

Guo R, Shi L, Ding X, Hu Y, Tian S, Yan D, Yang Y (2010) Effects of saline and alkaline stress on germination, seedling growth, and ion balance in wheat. Agronomy J. 102(4): 1252-1260.

Gupta A, Dixit SK, Senthil-Kumar M (2016) Drought stress predominantly endures Arabidopsis thaliana to Pseudomonas syringae infection. Front. Plant Sci. 7: 808.

Hasanuzzaman M, Nahar K, Fujita M (2013) Plant response to salt stress and role of exogenous protectants to mitigate saltinduced damages, In: Ecophysiology and Responses of Plants under Salt Stress (Eds: Ahmad P, Prasad MNV, Azooz MM), Springer-Verlag, New York. pp 25-87.

Hatzig S, Hanstein S, Schubert S (2010) Apoplast acidification is not a necessary determinant for the resistance of maize in the first phase of salt stress. J. Plant Nutr. Soil Sci. 173: 559-562. 
Horgan R, Kramers MR (1979) High performance liquid chromatogaphy of cytokinins. J. Chromatopraphy 173: $263-270$.

Iwasaki M, Fukamachi H, Imai A, Nonaka K (2011) Effects of summer and autumn water stress on fruit quality of medium-late maturing citrus 'Harehime'. Hort. Res. 10: 191-196.

Jackson M (1958) Soil Chemical Analysis. Prentice-Hall Inc., Englewood Cliffs, New Jersey, USA. pp 498

Juniper S, Abbott L (1993) Vesicular-arbuscular mycorrhizas and soil salinity. Mycorrhiza, 4: 45-57.

Kalefetoğlu T, Ekmekçi Y (2005) The effect of drought on plant sand tolerance mechanisms. G. U. J. Sci. 18(4): 723-740.

Kıpçak S, Ekincialp A, Erdinç Ç, Kabay T, Şensoy S (2019) Tuz stresinin farklı fasulye genotiplerinde bazı besin elementi içeriği ile toplam antioksidan ve toplam fenol içeriğine etkisi. YYÜ Tar. Bil. Derg. 29(1): 136144.

Kim YC, Cho MH, Kim SJ, Jang H (2008) The effect of phenolic resin, potassium titanate, and CNSL on the tribological properties of brake friction materials. Wear 264, 204.

Knudsen D, Peterson GA, Pratt PF (1982) Lithium, sodium and potassium, In: Methods of soil analysis-Part 2 (Eds. Page AL, Miller RH, Keeney DR), American Society of Agronomy, Madison, USA. pp 225-246.

Koshimizo K, Iwamura H (1986) Chemistry of Plant Hormones, (Editor: Takahashi N), CRC Press Inc., Florida. 154-199.

Ksouri R, Megdiche W, Debez A, Falleh H, Grignon C, Abdelly C (2007) Salinity effects on polyphenol content and antioxidant activities in leaves of the halophyte Cakile maritima. Plant Physiol. Biochem. 45: 244-249.

Lindsay WL, Norvell WA (1978) Development of a DTPA soil test for zinc, iron, manganese and copper. Soil Sci. Soci. American J., 42: 421-28.

López-Ráez JA, Flors V, García JM and Pozo MJ (2010) AM symbiosis alters phenolic acid content in tomato roots. Plant Sign. Behav. 5: 1138-1140.

Ludwig-Müller J (2010) Hormonal responses in host plants triggered by arbuscular mycorrhizal fungi, In: Arbuscular Mycorrhizas: Physiology and Function (Eds. Koltai $\mathrm{H}$ and Kapulnik Y), Springer, Netherlands. 169-190.

Mansour MMF (2000) Nitrogen containing compounds and adaptation of plants to salinity stress. Biol. Plant. 43: 491-500.
Martín-Rodríguez JA, Ocampo JA, Molinero-Rosales N, Tarkowská D, Ruíz-Rivero $O$ and García-Garrido JM (2015) Role of gibberellins during arbuscular mycorrhizal formation in tomato: new insights revealed by endogenous quantification and genetic analysis of their metabolism in mycorrhizal roots. Physiol. Plant 154: 66-81.

McMillen BG, Juniper S, Abbott LK (1998) Inhibition of hyphal growth of a vesicular-arbuscular mycorrhizal fungus in soil containing sodium chloride limits the spread of infection from spores. Soil Biol. Biochem. 30: 1639-1646.

Meixner C, Ludwig-Muller J, Miersch O, Gresshoff P, Staehelin C, Vierheilig H (2005) Lack of mycorrhizal autoregulation and phytohormonal changes in the supernodulating soybean mutant nts1007. Planta 222: 709-715.

Michalak A (2006) Phenolic compounds and their antioxidant activity in plants growing under heavy metal stress. Polish J. Environ. Stud. 15(4): 523-530.

Miransari M (2012) Role of phytohormone signaling during stress, In: Environmental Adaptations and Stress Tolerance of Plants in the Era of Climate Change (Eds. Ahmad P., Prasad M), Springer, New York. pp 381-393.

Mohammad A, Mittra B (2013) Effects of inoculation with stress-adapted arbuscular mycorrhizal fungus Glomus deserticola on growth of Solanum melogena L. and Sorghum sudanese Staph. seedlings under salinity and heavy metal stress conditions. Arch. Agron. Soil Sci. 59(2): 173-183.

Morris JW, Doumas P, Morris R, Zaer JB (1990) Cytokinins in vegetative and reproductive buds of Pseudotsuga menziesii. Plant Physiol. 9: 67-71.

Muchovej RM (2001) Importance of mycorrhizae for agricultural crops. University of Florida, Extension Instude of Food Agricultural Sciences, SS-AGR-170.

Olsen SR, Cole CV, Waterable FS, Dean LA (1954) Estimation of available phosphorus in soils by extraction with sodium bicarbonate. USPA Circular No: 939, Washington D.C.

Orujei Y, Shabani L, Sharifi-Tehrani M (2013) Induction of glycyrrhizin and total phenolic compound production in licorice by using arbuscular mycorrhizal fungi. Russ. J. Plant Physl. 60: 855-860

Parida AK, Das AB (2005) Salt tolerance and salinity effect on plants: a review. Ecotoxicol. Environ. Saf. 60: 324-349.

Prakash L, Prathapasenan G (1990) $\mathrm{NaCl}$ and gibberellic acid induced changes in the content of auxin, the activity of cellulose and pectin lyase during leaf growth in rice (Oryza sativa). Ann. Bot. 365: 251-257. 
Rivas-Ubach A, Sardans J, Perez-Trujillo M, Estiarte M, Penuelasa J (2012) Strong relationship between elemental stoichiometry and metabolome in plants. Proc. Natl. Acad. Sci. 109(11): 4181-4186.

Ruiz MJ, Rivero MR, Lo' pez-Cantarero I, Romero R (2003) Role of $\mathrm{Ca}^{2+}$ in the metabolism of phenolic compounds in tobacco leaves (Nicotiana tabacum L.). Plant Growth Regulation 41: 173-177.

Ruiz-Lozano JM (2003) Arbuscular mycorrhizal symbiosis and alleviation of osmotic stress. New perspectives for molecular studies. Mycorrhiza 13: 307-317.

Sannazzaro Al, Echeverria M, Alberto EO, Ruiz OA, Menendez AB (2007) Modulation of polyamine balance in lotus glaber by salinity and arbuscular mycorrhiza. Plant Physiol. Biochem. 45: 39-46.

Shams $M$, Yıldırım E, Ekinci $M$, Turan $M$, Dursun $E$, Parlakova F, Kul R (2016) Exogenously applied glycine betaine regulates some chemical characteristics and antioxidative defence systems in lettuce under salt stress. Hortic. Environ. Biotech. 57(3): 225-231.

Sharma MP, Adholeya A (2004) Effect of arbuscular mycorrhizal fungi and phosphorus fertilization on the post vitro growth and yield of micropropagated strawberry grown in a sandy loam soil. Can. J. Bot. 82(3): 322-328.

Sharma N, Aggarwal A, Yadav K (2017) Arbuscular mycorrhizal fungi enhance growth, physiological parameters and yield of salt stressed Phaseolus mungo (L.) Hepper. European J. Environ. Sci. 7(1): 513.

Sheng $M$, Tang $M$, Zhang FF, Huang YH (2011) Influence of arbuscular mycorrhiza on organic solutes in maize leaves under salt stress. Mycorrhiza 21: 423-430.

Shi GR, Cai QS, Liu QQ, Wu L (2009) Salicylic acidmediated alleviation of cadmium toxicity in hemp plants in relation to cadmium uptake, photosynthesis, and antioxidant enzymes. Acta Physiol. Plant 31: 969-977.

Siddiqui $\mathrm{M}$, Chand $\mathrm{M}$, Bhoday J, Tekkis $\mathrm{P}$, Abulafi AM, Brown G (2015) Correlation between MRI Detected Extra-Mural Vascular Invasion (mrEMVI) in Rectal Cancer and Metastatic Disease: a Meta-Analysis. PROSPERO 2015 CRD42015027923 Available from: https://www.crd.york.ac.uk/prospero/display_recor d.php?ID=CRD42015027923 (Erişim tarihi: 18 Eylül 2020)

Smith S, Read DJ (1997) Mycorrhizal Symbiosis. Second Edition. Academic Press, London. pp 605.

Sneha S, Rishi A, Dadhich A, Chandra S (2013) Effect of salinity on seed germination, accumulation of proline and free amino acid in Pennisetum glaucum (L.) R. Br. Pak. J. Biol. Sci. 17: 877-881.
Surender Reddy P, Jogeswar G, Rasineni GK, Maheswari M, Reddy AR, Varshney RK, Kavi Kishor PB (2015) Proline over-accumulation alleviates salt stress and protects photosynthetic and antioxidant enzyme activities in transgenic sorghum [Sorghum bicolor (L.) Moench]. Plant Physiol. Biochem. 94: 104-113.

Şensoy S, Demir S, Turkmen O, Erdinc Ç, Savur O (2007) Responses of some different pepper (C. annuum L.) genotypes to inoculation with two different arbuscular mycorrhizal fungi, Scientia Horticulturae 113: 92-95.

Takahama U, Oniki T (1997) Enhancement of peroxidasedependent oxidation of sinapyl alcohol by an apoplastic component, 4-coumaric acid ester isolated from epicotyls of Vigna angularis L. Plant and Cell Physiology 38: 456-462.

Tambussi EA, Bartoli CG, Beltrano J, Guiamet JJ, Araus JL (2000) Oxidative damage to thylakoid proteins in water-stressed leaves of wheat (Triticum aestivum). Physiologia Plantarum 108: 398-404.

Usha K, Saxena A, Singh B (2004) Rhizosphere dynamics influenced by arbuscular mycorrhizal fungus (Glomus deserticola) and related changes in leaf nutrient status and yield of Kinnow mandarin \{King (Citrus nobilis) $\times$ Willow Leaf (Citrus deliciosa)\}. Aust. J. Agric. Res. 55: 571-576.

Vural H, Eşiyok D, Duman i (2000) Kültür Sebzeleri. Ege Üniversitesi Basımevi, İzmir. 440s.

Walker TS, Bais HP, Halligan KM, Stermitz FR, Vivanco JM (2003) Metabolic profiling of root exudates of Arabidopsis thaliana. Agric. Food Chem. 51: 25482554.

Wang Y, Wang M, Li Y, Wu A, Huang J (2018) Effects of arbuscular mycorrhizal fungi on growth and nitrogen uptake of Chrysanthemum morifolium under salt stress. PLoS ONE 13(4): e0196408.

Yang C, Chong J, Kim C, Li C, Shi D, Wang D (2007) Osmotic adjustment and ion balance traits of an alkali resistant halophyte Kochia sieversiana during adaptation to salt and alkali conditions. Plant and Soil 294: 263-276.

Zhang YF, Feng G, Li XL (2003) The effect of arbuscular mycorrhizal fungi on the components and concentrations of organic acids in the exudates of mycorrhizal red clover. Acta Ecol. Sin. 23: 30-37.

Zhu JK (2002) Salt and drought stress signal transduction in plants. Annu. Rev. Plant Biol. 53: 247-273.

Zolman BK, Martinez N, Millius A, Adham AR, Bartel B (2008) Identification and characterization of Arabidopsis indole-3-butyric acid response mutants defective in novel peroxisomal enzymes. Genetics 180: 237-251. 